\title{
The screening of phytochemical and antioxidant activity of agarwood leaves (Aquilaria malaccensis) from two sites in North Sumatra, Indonesia
}

\author{
RIDWANTI BATUBARA ${ }^{1, v}$, SURJANTO ${ }^{2}$, T. ISMANELLY HANUM ${ }^{2}$, ARBI HANDIKA ${ }^{1}$, ODING AFFANDI ${ }^{1}$ \\ ${ }^{1}$ Faculty of Forestry, Universitas Sumatera Utara. Jl. Tridharma Ujung No. 1, Kampus USU Padang Bulan, Medan 20155, North Sumatra, Indonesia. \\ Tel.: +62-61-8220605, Fax.: +62-61-8201920, `email: ridwantibb@yahoo.com \\ ${ }^{2}$ Faculty of Pharmacy, Universitas Sumatera Utara. Jl. Tridharma Ujung No. 4, Kampus USU Padang Bulan, Medan 20155, North Sumatra, Indonesia.
}

Manuscript received: 7 August 2019. Revision accepted: 23 March 2020.

\begin{abstract}
Batubara R, Surjanto, Hanum TI, Handika A, Afandi O. 2020. Phytochemical screening and antioxidant activity of agarwood leaves (Aquilaria malaccensis) from two sites in North Sumatra, Indonesia. Biodiversitas 21: 1588-1596. Agarwood of gaharu (Aquilaria malaccensis Lamk) has an antioxidant activity which can reduce free radicals. This research was conducted to analyze the chemical compounds of agarwood, and the antioxidant activities from two different grown sites, Laru, and Hutanabolon Village. Ethanol extracts of the agarwood leaves (EEAL) were obtained through maceration method. The phytochemical screening included the examination of secondary plant metabolites, while antioxidant activity was determined by free radicals scavenging activity against 1,1diphenyl-2-picrylhydrazyl (DPPH). An observable parameter was the percentage of free-radical-reduction with different concentrations $(40,60,80$ and $100 \mathrm{ppm})$ and inhibitory concentrations $\left(\mathrm{IC}_{50}\right)$ value by using regression equation. The phytochemical screening result showed that simplicia and EEAL from Laru grown site contained secondary plant metabolites, such as steroid/triterpenoids, flavonoids, saponins, and tannins, while simplicia leaves of agarwood from Hutanabolon grown site contained alkaloids, steroid/triterpenoids, saponins, and tannins, However, EEAL from Hutanabolon was found to only contain alkaloids. The f antioxidant activity of EEAL from Laru $27.887 \pm 0.560$ ppm was not different from Hutanabolon $27.807 \pm 4.630$ ppm. The EEAL from both Laru and Hutanabolon had a very strong antioxidant activity.
\end{abstract}

Keywords: Agarwood leaves, antioxidant activity, ethanol extract, phytochemical

\section{INTRODUCTION}

The changes in community life, imprudent eating habit, and aging could lead to the formation of free radicals in body. Density of work activities tends to cause people to eat instant food and adopt unhealthy eating habits. Moreover, unhealthy food will contribute to free radicals accumulation in the body for long term. Also, a polluted environment, eating habits and lifestyle failure are able to stimulate the development of free radicals that could damage the body (Mega and Swastini 2010). Consuming foods or supplements containing antioxidants can neutralize free radicals by donating one proton atom to make free radicals more stable and not reactive. Research and utilization of agarwood or gaharu leaves as a source of antioxidants within tea product has been developed (Surjanto et al. 2019a). Secondary metabolites, such as flavonoids, terpenoids, and phenols, are considered to be anti-free radicals (antioxidant) (Mega and Swastini 2010). Agarwood leaves contain chemical compounds such as flavonoids, flavones, flavonols, and isoflavones. These chemical compounds are categorized as antioxidant sources (Surjanto et al. 2015), and safe for consumption (Batubara et al. 2016).

Agarwood is a non-timber forest product that is categorized as a natural potential of Indonesia's forests. This tree is frequently seen on the island of Sumatera, Java,
Kalimantan, Sulawesi, Maluku, Papua and Nusa Tenggara region of Indonesia. Agarwood is a resin obtained from the results of microbial infections in various trees family, such as Thymeleacea, Leguminosae and Euphorbiaceae. Among several species of agarwood, there are three species categorized as having good quality, namely Aquilaria malaccensis Lamk, Aquilaria filaria L. and Aetoxylon sympethallum (Steenis \& Domke) Airy Shaw). A. malaccensis is grown on the lowlands to the mountains area with an altitude of 0-750 meters above sea level and with rainfall below < $2000 \mathrm{~mm} / \mathrm{year}$. The suitable temperature is $27-32{ }^{\circ} \mathrm{C}$ with $70 \%$ of sunlight levels. This species grows in soft and sandy clay soil with $\mathrm{pH}$ ranging from 4.0-6.0 (Sumarna 2009).

Agarwood is found and endemic to North Sumatra. Young and old leaves of agarwood species of Wikstroemia tenuiramis Miq can be used as an alternative tea, with tannin content of below 5\% and very strong antioxidant activity categories (Surjanto et al. 2019b). Also, A. malaccensis is found to grow naturally in North Sumatera and spreads in several districts.

Based on earlier agarwood exploration in Mandailing Natal District and Central Tapanuli District, Indonesia, A. malaccensis was found to grow in forests. Therefore, it is necessary to perform a research in order to determine the chemical content and test the antioxidant activity of agarwood leaf ethanol extract based on its place of growth 
(in Laru Village, Tambangan Sub-district Mandailing Natal District, and Hutanabolon Village, Tukka Sub-district, Central Tapanuli District, Indonesia). Those two places are different, since Tukka Sub-district is near the sea at an altitude of 1-800 meters above sea level while Tambangan Sub-district is at an altitude of 1-2400 meters above sea level by wavy topography passing over mountains.

Leave contains various chemical compounds including 2 - (2-phenylethyl) chromone, phenolic acid, steroid, fatty acid, benzophenone, xanthonoid, flavonoid, terpenoid, and alkane that may be related to the advantageous properties pharmacologically (Adam et al. 2017). Tea is categorized based on the difference of tea plants' variety, types of tea, classes, market's name, and the location of tea production (Adam et al. 2017). The phytochemical compounds vary depending on the location sampling of the leaves (Asmaliyah et al. 2016). The difference of agarwood's growing areas with the same type and the impacts of chemical compounds and agarwood leave's antioxidants need to be observed.

The results of antioxidant activities showed that agarwood leaves extract from the plant growing naturally (type $W$. tenuiramis) and from the cultivated ones (type $A$. Mallacensis) had IC50 value of each 30.482 dan 41.130 ppm respectively, which were included in the category of having very strong antioxidant activities, and were decent to be developed as rich-in-antioxidant alternative tea (Batubara et al 2019). This research wants to observe whether the agarwood leaves from the plant grows naturally in different growing places have different chemical compounds (through phytochemical test) or not, and also the compounds observation through GCMS test with the difference of antioxidant activity. This is beneficial as information sources related to the growing areas as sources of agarwood tea.

\section{MATERIALS AND METHODS}

\section{Research location}

Leaf samples were taken from Laru Village, Tambangan Sub-district, Mandailing Natal District and Hutanabolon Village, Tukka Sub-district, Central Tapanuli District, North Sumatra Province, Indonesia (Figure 1). Phytochemical assay, extraction, and antioxidant activity assay were carried out at the Pharmacognosy Laboratory and Research Laboratory, Faculty of Pharmacy, Universitas Sumatera Utara, Indonesia. GCMS test was conducted in the Forestry Research and Development Agency, Bogor, Indonesia.

\section{Research materials}

Agarwood leaves were obtained from two different places (Laru and Hutanabolon).

\section{Research procedure \\ Plant sampling}

Sampling process was of agarwood leaves of $A$. malaccensis from Laru and Hutanabolon. Plant identification was performed at Medanense Herbarium, Department of Biology, Universitas Sumatera Utara, Medan, Indonesia.

\section{Raw material preparation}

Agarwood leaves were cleaned of dirt with flowing water, then were spread on parchment paper until the excess water was fully absorbed. The leaves were dried in the drying cubinet at a temperature of $40^{\circ} \mathrm{C}-50^{\circ} \mathrm{C}$. The purpose was to get the simplicia that was not easily damaged, so it can be stored for a long time (Ditjen POM, 1995). The dried leaves were made into powder using a blender. Lastly, simplicia powder was inserted into a sunprotected container before extraction process was conducted.
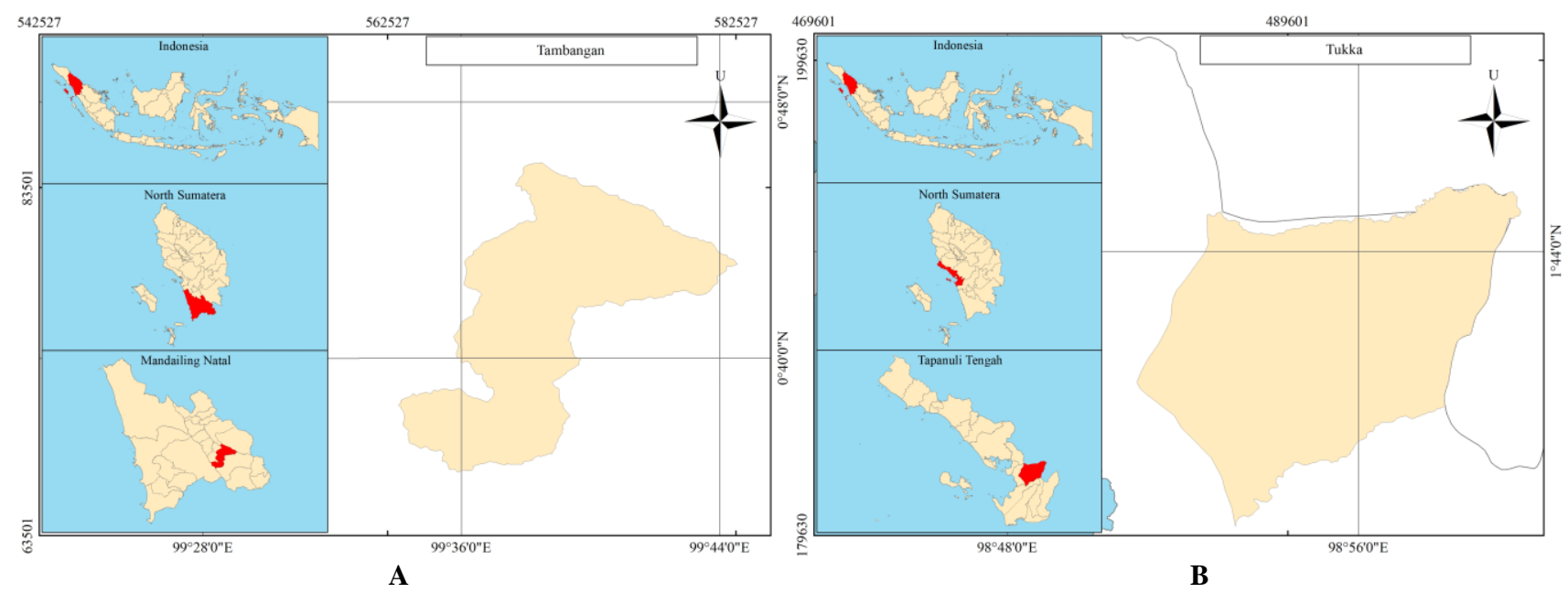

Figure 1. Location of research in North Sumatra Province, Indonesia. A. Tambangan Sub-district, Mandailing Natal District, B. Tukka Sub-district, Tapanuli Tengah District 


\section{Water content determination}

Water content was determined using Gravimetry method, with 3 repetitions.

\section{Phytochemical screening, tannin content test, and GC-MS} analysis

Phytochemical screening is a qualitative chemical examination of biologically active compounds (secondary metabolites) contained in simplicia and plant extracts. These compounds are organic compounds such as alkaloids, glycosides, flavonoids, steroids/terpenoids, tannins, and saponins. In addition, screening is the initial step in examining the plant to prove the presence or absence of certain chemical compounds that can be associated with biological activity (Farnsworth 1996). Phytochemical screening was done using standard procedures (Ditjen POM, 1995). Testing of tannin content used Lowenthal Proctermethod (Department of Health 2000). Shimadzu GCMS-QP2010 Ultra SHIMADZU was used as Gas Chromatography-Mass Spectrometry (GC-MS) tool.

\section{Ethanol extract of agarwood preparation}

Extract preparation was conducted with maceration by $96 \%$ ethanol solvent with the following procedure: $200 \mathrm{~g}$ of dried powder was put into a glass vessel, poured with 1500 $\mathrm{mL}$ of $96 \%$ ethanol, closed, left for 5 days protected from light and occasionally stirred. After 5 days the mixture was covered (strained), and washed with $96 \%$ ethanol sufficiently up to $2000 \mathrm{~mL}$, then moved in a closed vessel and left in a cool place protected from light for 2 days, then two days later, it was poured and filtered. Macerate was concentrated using a rotary evaporator at a temperature of $40^{\circ} \mathrm{C}$ until a concentrated macerate was obtained, then was dried using the freeze dryer so that dried extract was obtained (Surjanto et al. 2019a).

\section{Antioxidant assay via UV-visible spectrophotometry analysis (Surjanto et al. 2015)}

\section{The principle of DPPH radical scavenging activity}

This was to investigate the ability of the test sample to reduce the oxidation process of DPPH free radicals in methanol solution, resulting in a change in DPPH color from purple to yellow with an $\mathrm{IC}_{50}$ value which was defined as the total amount of antioxidant necessary to decrease the initial DPPH radical concentration by $50 \%$.

\section{Blank solution preparation}

DPPH $0.5 \mathrm{~mm}$ solution (200 ppm concentration) was pipetted for as much as $5 \mathrm{~mL}$ and then put into a $25 \mathrm{~mL}$ flask. The volume was adjusted with methanol to the marked line (concentration of $40 \mathrm{ppm}$ ).

\section{Maximum absorption wavelength determination}

DPPH solution with a concentration of $40 \mathrm{ppm}$ was set to be homogeneous and its absorption was measured at a wavelength of $400-800 \mathrm{~nm}$.

\section{Main solution preparation}

A total of $25 \mathrm{mg}$ of agarwood leaf extract was weighed and then dissolved in a $25 \mathrm{~mL}$ flask with methanol. Then, the volume was adjusted to methanol to the marked line (concentration of $1000 \mathrm{ppm}$ ).

\section{Test solution preparation}

The main solution was pipetted for as much as $1 \mathrm{~mL}$; $1.5 \mathrm{~mL} ; 2 \mathrm{~mL} ; 2.5 \mathrm{~mL}$, and then put into a $25 \mathrm{~mL}$ flask to result in a solution with various concentrations of $40 \mathrm{ppm}$, $60 \mathrm{ppm}, 80 \mathrm{ppm}, 100 \mathrm{ppm}$ respectively. Then, in each of the flask, it was added with $5 \mathrm{~mL}$ DPPH $0.5 \mathrm{~mm}$ solution (concentration $40 \mathrm{ppm}$ ) and the volume was adjusted with methanol up to the marked line. Then, it was stored in a dark place and the absorption was measured with visible spectrophotometer at a wavelength of $516 \mathrm{~nm}$, at intervals of 5 minutes ranging from 0 minutes to 30 minutes. This absorption measurement was performed with 3 repetitions.

\section{The percentage inhibition activity}

The percentage inhibition activity was calculated by the following equation (Andayani et al. 2008; Gagoi et al. 2018; Gao et al. 2019):

DPPH scavenging effect $(\%)=[($ Acontrol - Asample $) /$ Acontrol $\times 100]$

Where:

$\mathrm{A}_{\text {control }}=$ Absorbance without sample

$\mathrm{A}_{\text {sample }}=$ Absorbance of sample

\section{$I C_{50}$ value determination}

$\mathrm{IC}_{50}$ value is a number indicating the concentration of the test sample $(\mu \mathrm{g} / \mathrm{mL})$ which provides DPPH reduction of $50 \%$ (able to reduce the DPPH oxidation process by $50 \%$ ). In particular, a value of $0 \%$ reveals a non-antioxidant activity, while a value of $100 \%$ indicates a total reduction and further testing needs to be continued with dilution of the test solution to investigate the concentration limit of its activity. The results are entered into the regression equation $(\mathrm{Y}=\mathrm{AX}+\mathrm{B})$ with extract concentration (ppm) as abscissa (X axis) and soaking percentage (antioxidant) value as the ordinate (Y axis).

In specific, a compound is categorized as a powerful antioxidant if the $\mathrm{IC}_{50}$ value is less than $50 \mathrm{ppm}$, followed by strong, medium and weak with $\mathrm{IC}_{50}$ value of $50-100$ ppm, 100-150 ppm, and 151-200 ppm respectively (Mardawati et al. 2008).

\section{RESULTS AND DISCUSSION}

\section{Simplicia water content determination}

The results of simplicia average water content determination revealed that the agarwood leaves from the two different growth sites fulfilled the simplicia water content requirements (Ditjen POM 1995) since it was found to not exceeding $10 \%$ in value (Table 1). The determination of water content is performed to provide a minimal boundary of water content that can still be permitted in the dried agarwood leaves. The determination of water content is also useful for presuming the durability 
or resilience of samples in storage with the result that relates to the quality of the dried agarwood leaves.

\section{EEAL content}

The compounds contained in ethanol extract are categorized as polar compounds since ethanol is an organic and semi-polar organic solvent. The solvent also does not affect the color yield of each. The solution was black in color. The extract of all types of leaves was black and thick The results of EEAL are describe in Table 1.

Table 1 shows that the yield of ethanol extract from Hutanabolon Village was higher. The resulted extract will depend on several factors including the natural conditions of the compound, the extraction method, sample particle size, storage conditions and time, extraction time, and the ratio of the amount of solvent to the number of samples (Harborne 1987). The extraction yield from Hutanabolon Village is found to be higher since the obtained leaves are dominated by young leaves, resulting in more extractives to be dissolved.

\section{Phytochemical screening result}

Phytochemical screening results reveal that simplicia and EEAL are positively containing steroid/triterpenoid, flavonoids, saponins and tannins compound for agarwood leaves originating from Laru Village (Table 2). However, the agarwood leaves obtained from Hutanabolon Village are showing different results. The simplicia of agarwood leaves from Hutanabolon Village contains alkaloids, steroids/triterpenoids, saponins and tannins. Moreover, EEAL from Hutanabolon Village only contains alkaloid compounds. In general, chemical composition is relatively influenced by plant habitats (Firdiyani 2015). Plant growth and development (including secondary metabolites) are strongly affected by environmental factors, such as height (Herlina et al. 2017). In detail, description of the compounds is as follows:

\section{Alkaloids}

The results of phytochemical screening using Meyer and Bouchard at reagents showed that the alkaloid compounds were positive in the ethanol extract of agarwood leaves from Hutanabolon Village, but was negative in the agarwood leaves from Laru. The agarwood leaves from Hutanabolon were taken from trees with a diameter of less than $10 \mathrm{~cm}$, which is the pole phase, where the tree has not reached maturity for diameter, a mature tree has at least $20 \mathrm{~cm}$ in diameter. The growth rate can increase the biosynthesis of secondary metabolites, since one secondary metabolite is a saponins compound (Khristyana et al. 2005)

\section{Steroids/triterpenoids}

Phytochemical screening results revealed that agarwood leaves simplicia and EEAL from Laru Village positively contain steroid/triterpenoid compounds. However, it is only agarwood leaves simplicia from Hutanabolon Village which positively contains steroid/triterpenoid compounds. These results were obtained from testing with the addition of glacial $\mathrm{CH}_{3} \mathrm{COOH}$ and concentrated $\mathrm{H}_{2} \mathrm{SO}_{4}$ with slow shaking treatment and left for several minutes. Steroids give blue or green colors, while triterpenoids give red or violet colors. Triterpenoids are natural compounds formed by biosynthetic processes and are widely distributed in the world of plants and animals (Sirait 2007). Furthermore, triterpenoid compounds are known to possess certain physiological activities such as antifungal, antibacterial, antiviral, liver damage, menstrual disorders, and can treat diabetes (Astiti Asih et al. 2010).

\section{Flavonoids}

A positive flavonoid compound in simplicia and ethanol extracts originating from Laru village was observed by the formation of yellow color in simplicia and red color in ethanol extracts in the amyl alcohol layer. On the other hand, it was only simplicia from Hutanabolon Villages containing positive flavonoid compounds. Flavonoids cover many pigments and are found throughout the plant world. They are also the largest group of phenol compounds found in nature. Moreover, these compounds are red, purple and blue dyes, as well as yellow dyes found in plants. A number of flavonoids have a bitter taste, so that they can resist certain types of caterpillars. Flavonoids are commonly found in plants as glycosides and are existed in all parts of the plant including fruit, pollen, and roots (Sirait 2007). Furthermore, flavonoids in plants are useful for luring insects and other animals to help the process of pollinating and spreading seeds. Flavonoids can be useful for human life. In particular, with small doses, it works as a stimulant for heart, and hesperidin affects the capillaries. Hydroxylated flavones function as diuretics and antioxidants in fats (Sirait 2007).

\section{Tannins}

Tannins are generally defined as polyphenol compounds with high molecular weight (more than 1000) and are able to form complexes with protein (Yildirim and Kutlu 2015). The result of tannins presence examination showed that both agarwood leaves simplicia and ethanol extracts from Laru Village appeared to be blackish-green meaning an indication of the presence of tannin compounds.

Table 1. EEAL result and simplicia average water content value from the two different grown sites

\begin{tabular}{lcc}
\hline Agarwood leaves grown site & EEAL (g) & $\begin{array}{c}\text { Water } \\
\text { content (\%) }\end{array}$ \\
\hline Laru & $5.32 \pm 0.11$ & $7.66 \pm 0.41$ \\
Hutanabolon & $8.70 \pm 0.25$ & $9.75 \pm 0.18$ \\
\hline
\end{tabular}

Table 2. Phytochemical screening result

\begin{tabular}{lcccc}
\hline \multirow{2}{*}{ Compounds } & \multicolumn{5}{c}{ Agarwood leaves grown site } \\
\cline { 2 - 5 } & \multicolumn{3}{c}{ Laru } & \multicolumn{3}{c}{ Hutanabolon } \\
\cline { 2 - 5 } & Simplicia & Extract & Simplicia & Extract \\
\hline Alkaloids & - & - & + & + \\
Flavonoids & + & + & - & - \\
Tannins & + & + & + & - \\
Saponins & + & + & + & - \\
Triterpenoids & + & + & + & - \\
\hline
\end{tabular}


Table 3. Tannin content (\%) of agarwood leaves

\begin{tabular}{lc}
\hline Agarwood leaves grown site & Tannin content (\%) \\
\hline Laru & $5.6200 \pm 0.4158$ \\
Hutanabolon & $3.0856 \pm 0,2266$ \\
\hline
\end{tabular}

Tannins are active compounds of secondary metabolites that are known to have several properties such as astringent, anti-diarrhea, antibacterial and antioxidant (Desmiaty et al. 2008). The tannins content of agarwood leave can be seen in Table 3. Agarwood leaves from Laru Village had higher concentrations than agarwood leaves from Hutanabolon Village.

\section{Saponins}

Saponins are strong surface-active compounds, becoming foam when shaken in water and, at low concentrations, often causing hemolysis of red blood cells (Sirait 2007). The results of agarwood leaves simplicia and ethanol extracts from Laru Village showed that foam was formed after shaking process. After the addition of hydrochloric acid $(\mathrm{HCl}) 2 \mathrm{~N}$, the foam did not disappear and became stable. The results of agarwood leaf simplicia test and ethanol extract from Hutanabolon Village, indicated that it was only agarwood leaves simplicia showing foam formation after shaking process. This is caused by ethanol as a universal solvent, dissolving polar and nonpolar analytes. In particular, Ethanol can attract alkaloids, steroids, saponins, and flavonoids from plants (Thompson 1985). The saponin compounds tend to be attracted by semi-polar solvents such as ethanol. The emergence of foam in the saponin test indicates the presence of glycosides which have the ability to produce foam in hydrolyzed water into glucose and other compounds (Marliana et al. 2005).

Phytochemical screening test results indicated differences in leaf samples from 2 growing places. This was based on the growth stages of two trees which were different. Samples from Laru Village were obtained from mature trees. They were planted around rubber stands but their age was unknown because they grew wild. On the other hand, samples from Hutanabolon Village were still at the pole growth stage and growing around riverside in pristine forests. The different growth stages contributed to the difference in content such as saponins, which was only found in samples from the Hutabolon village. Another factor causing differences in the chemical content of agarwood leaves were age and grown site condition. However, these factors were not comprehensively examined.

The difference in phytochemical screening results between simplicia and extracts for samples from Hutanabolon was caused by the solvent and the extraction process. Optimization in terms of extraction was still not optimum, so that the desired compound was not dissolved.

The leaves contained various chemical constituents including 2-(2-phenylethyl) chromones, phenolic acids, steroids, fatty acids, benzophenones, xanthonoids, flavonoids, terpenoids, and alkanes that might be related to beneficial pharmacological properties (Adam et al. 2017). A number of them were species-specific, but methods of extraction might also affect the composition.

The phytochemical compounds of plants have potentially significant applications in human health care as well as in corrosion field. The presence of each secondary metabolite in Agarwood leaves extracts gave a justification for the traditional use of the plant in treating various health problems. For instance, detection of alkaloids in Agarwood leaves extracts was of great importance, since significant quantities of alkaloids could be used as antimalaria, analgesic, antispasmodic, bactericidal and stimulants, which are all pharmaceutical properties of the plant. The presence of alkaloids in Agarwood leaves extracts justifies the use of the plant to treat toothache, colic, severe headache, rheumatism and pains during pregnancy (Asmaliyah et al. 2016).

\section{Maximum absorption wavelength $\left(\lambda_{\text {maks }}\right)$ determination result}

The results of the antioxidant activity test of agarwood leaf ethanol extract were measured by DPPH scavenging effect. Absorbance measurements were performed at the maximum absorption wavelength, where maximum absorption occurred. In this study, the maximum wavelength $\left(\lambda_{\max }\right)$ of DPPH still remained in the solution. Measurement of the maximum absorption of $40 \mathrm{ppm} \mathrm{DPPH}$ solution in methanol was carried out using a UV-Visible spectrophotometer.

The measurement results indicate that the DPPH solution in methanol produces maximum absorption at a wavelength of $516 \mathrm{~nm}$. It is due to a condition that the change in absorption for each unit of concentration is the greatest to be recorded at that wavelength number. This is in accordance with the statement of Molyneux (2004) which stated that $\lambda_{\max }$ is a measurement that gives maximum absorption.

DPPH free radical reduction activity based on the ability of test materials to reduce or capture DPPH radicals can be seen from the purple discoloration of DPPH solution, after being mixed with the test sample to produce yellow color. Therefore, it can be concluded that the ethanol extract of agarwood leaves possesses antioxidant properties in DPPH test. Agarwood leaves have the potential as an antioxidant, for containing groups of compounds that are potential as antioxidants, namely flavonoid compounds, according to the results of phytochemical tests.

\section{The DPPH free radical prevention result by agarwood leaves extract test sample}

The antioxidant ability of EEAL is known by employing parameters of antioxidant activity with absorbance percentage. Antioxidant ability was measured in the $30^{\text {th }}$ minute as a decrease in absorption of DPPH solution (DPPH free radical uptake) due to the addition of test solutions. The absorption value of DPPH solution was calculated as the percentage of absorbance.

The antioxidant activity of agarwood leaves ethanol extract was obtained from absorbance measurements by 
DPPH method at the $30^{\text {th }}$ minute with the addition of test solutions with various concentrations of $40 \mathrm{ppm}, 60 \mathrm{ppm}$, $80 \mathrm{ppm}, 80 \mathrm{ppm}$, and $100 \mathrm{ppm}$ respectively. DPPH with the test solution was then compared with the control. Positive control used was ascorbic acid (Vitamin C). The results discovered that the decrease in absorbance value occurred along with the increase of concentrations. Furthermore, average value of reduction percentages in each increase in the concentration of the test sample is provided in Table 4.

Free radicals are atoms or molecules that have unpaired electrons, making them possess high activity to attract electrons from other compounds (Harun and Syar'i 2002). DPPH free radical uptake activity based on the ability of the test material to reduce or capture DPPH radicals can be observed by the change of DPPH solution color after being mixed with the test sample from purple to yellow. Thus, it can be concluded that in DPPH analysis, ethanol extract of agarwood leaves has antioxidant properties. Furthermore, agarwood leaves contain potent antioxidants which are generally flavonoid compounds.

\section{IC50 (Inhibitory Concentration) value analysis}

The results of the antioxidant activity test of EEAL from Laru and Hutanabolon are shown in Table 5. Ethanol extract of agarwood leaves from two grown sites is categorized as a very strong antioxidant since it is less than $50 \mathrm{ppm}$. This result is comparable to ascorbic acid, which is also a very powerful antioxidant. In fact, the antioxidant activity of agarwood leaves from two grown sites are in the same category as ascorbic acid $(<50 \mathrm{ppm})$. This is due to the estimation of active compounds as antioxidant content in the extract.

Ethanol extract of agarwood leaves from two grown sites is categorized as a very strong antioxidant since it is less than $50 \mathrm{ppm}$. This result is comparable to ascorbic acid, which is also a very powerful antioxidant. In fact, the antioxidant activity of agarwood leaves from 2 grown sites are in the same category as ascorbic acid $(<50 \mathrm{ppm})$. This is due to the estimation of active compounds as antioxidant content in the extract.

Table 4 The average reduction percentage result of EEAL free radical based on grown site

\begin{tabular}{|c|c|c|c|}
\hline \multirow[b]{2}{*}{ Minute } & \multirow[b]{2}{*}{$\begin{array}{c}\text { Concentration } \\
(\text { ppm })\end{array}$} & \multicolumn{2}{|c|}{ Absorbance percentage } \\
\hline & & $\begin{array}{c}\text { EEAL from } \\
\text { Laru }\end{array}$ & $\begin{array}{l}\text { EEAL from } \\
\text { Hutanabolon }\end{array}$ \\
\hline \multirow{5}{*}{$30^{\text {th }}$} & 0 & 0.00 & 0.00 \\
\hline & 40 & 93.80 & 94.70 \\
\hline & 60 & 93.81 & 94.90 \\
\hline & 80 & 93.97 & 87.80 \\
\hline & 100 & 94.00 & 89.40 \\
\hline
\end{tabular}

Table 5. The $\mathrm{IC}_{50}$ value (ppm) of EEAL from Laru and Hutanabolon and ascorbic acid

\begin{tabular}{lc}
\hline $\begin{array}{c}\text { Agarwood leaves and positive } \\
\text { control }\end{array}$ & $\begin{array}{c}\text { Antioxidant activity } \\
\text { (ppm) }\end{array}$ \\
\hline Ascorbic acid & $2.6800 \pm 0.090$ \\
Grown Site at Laru & $27.887 \pm 0.560$ \\
Grown Site at Hutanabolon & $27.807 \pm 4.630$ \\
\hline
\end{tabular}

The ability of the sample to trap DPPH as a free radical in methanol solution with an $\mathrm{IC}_{50}$ value was used as a parameter to determine the antioxidant activity of the test sample (Prakash 2001). Inhibition Concentration $\left(\mathrm{IC}_{50}\right)$ is the concentration of an antioxidant that can cause $50 \%$ of DPPH to lose its radical characteristic or the concentration of an antioxidant that gives a 50\% inhibition. In particular, substances that have high antioxidant activity will have a low $\mathrm{IC}_{50}$ value.

The DPPH method in determining antioxidant activity was chosen due to the ease and availability of apparatus and materials. Also, this decision has taken based on previous research. The results of the antioxidant activity test showed that the ethanol extract of A. malaccensis leaves from Sigiring-giring and S. circles II had $\mathrm{IC}_{50}$ values of 56.985 and $44.382 \mu \mathrm{g} / \mathrm{mL}$ respectively, with strong and very strong antioxidant activity categories (Surjanto et al. 2019a). Potential antioxidant compounds can be predicted from the phenolic class, flavonoids, and alkaloids which are polar compounds (Enggiwanto et al. 2018). Most antioxidant compounds derived from plant sources possess wide variations and chemical properties (Fitriana et al. 2016). On the other hand, phytochemical screening produces positive flavonoid compounds for samples from Laru grown site. Flavonoid group has the ability to transform to produce compounds with higher activity of antioxidants (Kuntorini et al 2016). In conclusion, the antioxidant activity is increasing along with the increasing of flavonoid content (Soekmanto et al. 2007).

In addition, $\mathrm{IC}_{50}$ value is inversely proportional to the potential of free radical reduction. The greater the $\mathrm{IC}_{50}$ value obtained, the smaller the potential for antioxidant activity, which means the concentration needed to produce free radical reduction activity is $50 \%$ greater. The results of the study concluded that the ethanol extract of agarwood leaves has very strong antioxidant activity. Werdashari (2014) described that various plants commonly consumed in Indonesia contain antioxidants. The results of agarwood leaves extract (A. malaccensis) from various grown sites showed that it has potential to be a raw material for antioxidant tea to consume.

Advanced compound analysis was based on antioxidant test results conducted through GCMS test, and the chromatogram result for the agarwood leaves from Laru and Hutanabolon Villages can be seen in Figures 2 and 3. Search results from the Library of compounds are listed in Tables 6 and 7.

The result of GCMS test shows various compounds in agarwood leaves. There are 11 types of compound with more than 3 percent concentration found in agarwood leaves from Laru Village, the primary compound with the highest concentration is Octadecanoic acid (CAS) Stearic acid. Octadecanoic acid (stearic acid) is categorized as an acid compound. Vitamin $\mathrm{C}$ basically belongs to be chemically acidic. Vitamin $\mathrm{C}$ is a powerful antioxidant with its chemical name, ascorbic acid. Octadecanoic acid played a big role in this research as powerful antioxidant value in agarwood leaves from Laru Village. 


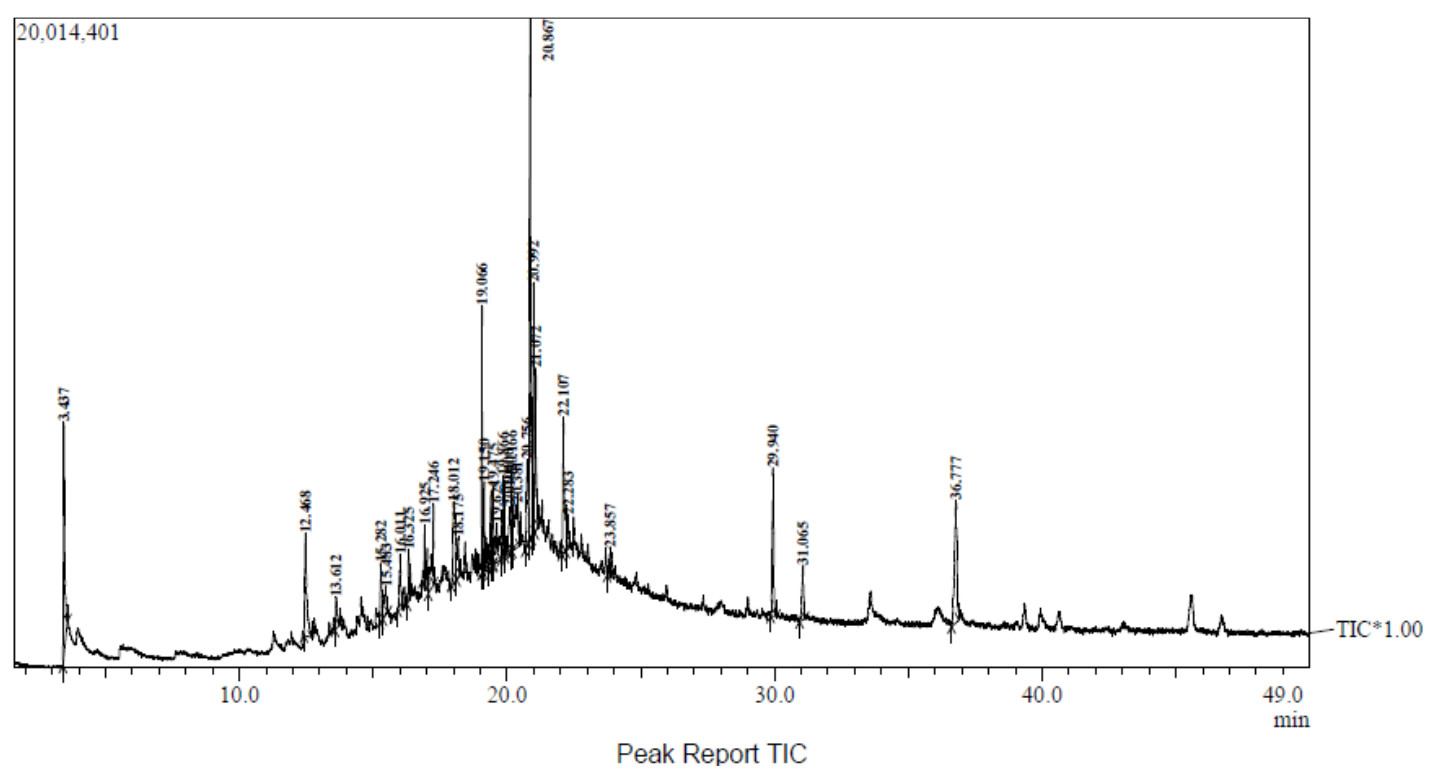

Figure 2. GC-MS chromatogram of agarwood leaves A. malaccensis from Laru Village, North Sumatra, Indonesia

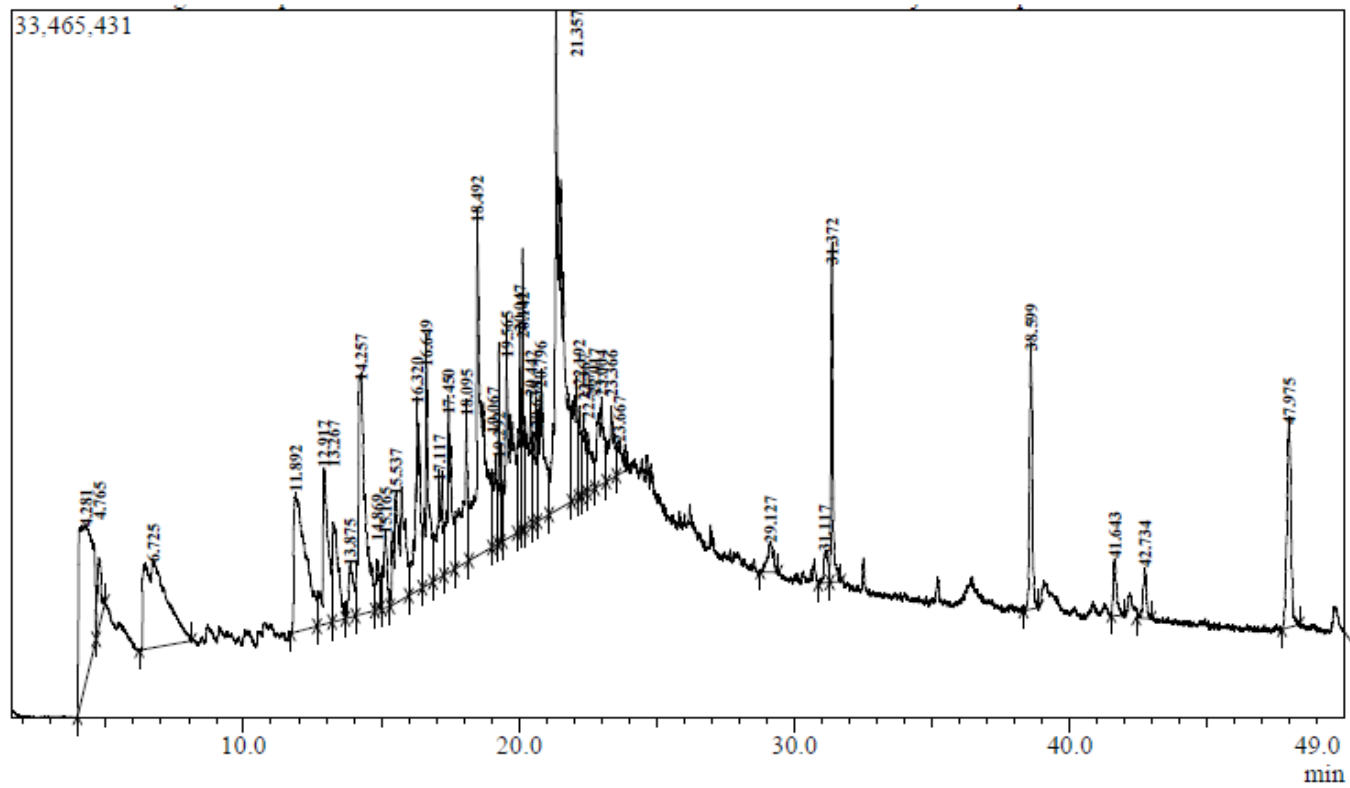

Peak Report TIC

Figure 3. GC-MS chromatogram of agarwood leaves A. malaccensis from Hutanabolon Village, North Sumatra, Indonesia

There are 10 types of compound with more than 3 percent concentration found in agarwood leaves from Hutanabolon Village, the primary compound with the highest concentration is Cyclopropyl carbinol. Cyclopropyl carbinol compound is classified as acid group, so that agarwood leaves from Hutanabolon Village also have powerful antioxidant activity in this research.

The chemical potential and significance of agarwood leaves based on community knowledge and research have been explained by Hasim et al. (2016). Phytochemicals from ethanol, methanol extract and water extract of agarwood leaves from several species revealed the presence of flavonoids, tannins, and saponins consistently. Furthermore, alkaloids and terpenoids were also identified (Dash et al. 2008; Huda et al. 2009; Khalil et al. 2013). In addition, identification of phytochemicals is important to control the quality and standardization of extracts, such as in the development of food supplements, herbal preparations or medicines from natural sources. 
Table 6. Compounds present in agarwood leaves A. malaccensis from Laru Village, North Sumatra, Indonesia using GC-MS analysis

\begin{tabular}{llll}
\hline R. time & Area & Conc. $\%$ & Name \\
\hline 3.437 & 22750279 & 6.39 & Carbon dioxide (CAS) Dry ice \\
12.468 & 16215794 & 4.55 & 1-borabicyclo[4.3.0]nonane \\
18.012 & 15799892 & 4.44 & Akuammilan-17-ol, 10-methoxy- (CAS) \\
19.066 & 11276653 & 3.17 & 1-Dodecene (CAS) Adacene 12 \\
20.756 & 10838880 & 3.04 & 9,12-Octadecadienal (CAS) \\
20.867 & 46250294 & 12.99 & Octadecanoic acid (CAS) Stearic acid \\
20.992 & 30186450 & 8.48 & 9,15-Octadecadienoic acid, methyl ester (CAS) METHYL 9,15-OCTADECADIENOATE \\
21.072 & 13051751 & 3.66 & 9,15-Octadecadienoic acid, methyl ester (CAS) METHYL 9,15-OCTADECADIENOATE \\
22.107 & 15085521 & 4.24 & 9-Octadecenoic acid (Z)- (CAS) Oleic acid \\
29.940 & 16882863 & 4.74 & trans-Farnesol \\
36.777 & 25191066 & 7.07 & Tricosane, 2-methyl- (CAS) 2-Methyltricosane \\
\hline
\end{tabular}

Table 7. Compounds present in agarwood leaves A. malaccensis from Hutanabolon Village, North Sumatra, Indonesia using GC-MS analysis

\begin{tabular}{llll}
\hline R. time & Area & Conc. $\%$ & Name \\
\hline 11.651 & 234129943 & 8.09 & Cyclohexanone (CAS) Anon \\
12.632 & 214423381 & 7.41 & Benzenesulfonic acid, 4-hydroxy- (CAS) Benzenesulfonic acid, p-hydroxy \\
13.064 & 106193222 & 3.67 & 2-Cyclopenten-1-one, 2-hydroxy-3-methyl- (CAS) Corylon \\
14.016 & 309657571 & 10.69 & Cyclopropyl carbinol \\
15.548 & 129486858 & 4.47 & Phenol, 4-ethyl-2-methoxy- (CAS) p-Ethylguaiacol \\
20.194 & 134442691 & 4.64 & NEOPHYTADIENE \\
21.227 & 225355393 & 7.78 & Hexadecanoic acid (CAS) Palmitic acid \\
21.306 & 219912260 & 7.59 & Oxacycloheptadec-8-en-2-one (CAS) Ambrettolide \\
37.135 & 157926830 & 5.45 & Tetratetracontane (CAS) n-Tetratetracontane \\
45.912 & 105826887 & 3.65 & Tetratetracontane (CAS) n-Tetratetracontane \\
\hline
\end{tabular}

Agarwood has been used in a number of different communities, with most of the community has been using it as a drug-related to anti-inflammatory activities and those associated with it. For instance, it is used to treat rheumatism, arthritis, body aches, asthma and gout (Hasim et al. 2016). In China, Ethnopharmacology Aquilaria spp. is used as a treatment for stomach problems, coughing, rheumatism, and high fever. Moreover, it is also used as a sedative, analgesic and carminative agent. While for Indian society, it is used among other things for the treatment of diarrhea, dysentery, vomiting, anorexia, mouth and tooth disease, facial paralysis, chills, sprains, and broken bones. In Indonesia, it is used for treating joint pain (Hasim et al. 2016).

The leaves of $A$. sinensis are applied in traditional medicine for treatment of trauma-related illnesses such as fractures and bruises (Zhou et al. 2008). The leaves of $A$. crassna are useful as a supplement to combat various health conditions such as high blood pressure, constipation, headache and diabetes (Pranakhon et al. 2011). Agarwood tea is made from the leaves of Aquilaria (Adam et al. 2017). Tea composition differs by species, plant variety, season, climate, leaf age, plucking position and horticultural practices (Kuo et al. 2005).
In conclusion, phytochemical screening of agarwood leaves from Laru result revealed that both the simplicia and agarwood leaves ethanol extract to contain similar compounds, namely steroids/triterpenoids, flavonoids, saponins, and tannins. On the other hand, the simplicia agarwood leaves from Hutanabolon was found to contain alkaloids, steroids/triterpenoids, saponins, and tannins. In addition, ethanol extract of agarwood leaves from Hutanabolon was found to only contain alkaloid compounds. The results of antioxidant activity test indicated that there was no difference in the antioxidant activity of agarwood leaves. Ethanol extract based on leaf samples revealed a very strong antioxidant activity.

\section{ACKNOWLEDGEMENTS}

Authors would like to acknowledge Directorate of Research and Community Service, Directorate General of Research Empowering and Development Ministry of Research, Technology and Higher Education of Indonesia for providing funding towards this research with Fundamental Grant Scheme, 2018-2019. 


\section{REFERENCES}

Andayani R, Maimunah, Lisawati Y. 2008. Determination of antioxidan activity, total phenolic content, and lycopene in tomatoes (Solanum lycopersicum L). Jurnal Sains dan Teknologi Farmasi 13 (1): 31-37.

Astiti Asih IAR, Gunawan IWG, Desi Ariani NM. 2010. Isolation and identification of triterpenoid compounds from N-hexane extract kepuh leaves (Sterculia foetida L.) and free antiradical activity test. Jurnal Kimia 4 (2): 135-140.

Asmaliyah, Hadi EE, Muslimin I, Turjaman M, Thalib I. 2016 Quantitative preliminary phytochemical screening of aqueous extracts of leaves of Oroxylum indicum from five different places in Sumatra Island, Indonesia. Intl J Pharmacogn Phytochem Res 8 (11): 1863 1869.

Batubara R, Surjanto, Sihombing TM, Ginting H. 2016. The safety of tea agarwood (Aquilaria malaccensis) from tree induction through test of toxicity subchronic oral 90 days. Biofarmasi 14 (2): 69-76.

Batubara R, Nurminah M, Hanum TI, Surjanto. 2019. Potency of gaharu leaves that grows naturally and cultivated as raw material of antioxidant-rich tea. Proceedings International Conference on Environmental Awareness for Sustainable Development in conjunction with International Conference on Challenge and Opportunities Sustainable Environmental Development, ICEASD \& ICCOSED 2019, 1-2 April 2019, Kendari, Indonesia. DOI 10.4108/eai.1-4-2019.2287276

Dash M, Patra JK, Panda PP. 2008. Phytochemical and antimicrobial screening of extracts of Aquilaria agallocha Roxb. Afr J Biotechno 7: 3531-3534.

Department of Health (DEPKES). 2000. Common standard parameters of medicinal plant extracts. Directorate General of Drug and Food Supervision, Jakarta. [Indonesian]

Desmiaty Y, Ratih H, Dewi MA, Agustin R . 2008. Determination of the total amount of tannin in daun jati leaves (Guazuma ulmifolia Lamk) and sambung darah leaves (Excoecaria bicolorHassk.) by colorimetry with Prussian blue reagents. Ortocarpus 8: 106 - 109.

Enggiwanto S, Istiqomah F, Daniati K, Roanisca O, Mahardika RG. 2018 Extraction of pelawan leaves (Tristaniopsis merguensis) as an antioxidant using microwave-assisted extraction (MAE). Indon J Pure Appl Chem 1 (2): 50-55.

Fitriana WD, Ersam T, Shimizu K, Fatmawati S. Antioxidant activity of Moringaoleifera extracts. Indones. J. Chem 16 (3): 297 - 301

Firdiyani F, Agustini TW, Ma'ruf WF. 2015. Extraction of bioactive compounds in natural antioxidants fresh Spirulina platensis with different solvents JPHPI (Journal of Fishery Products Processing Indonesia) 18 (1): 28-37.

Farnsworth NR. 1996. Biological and phytochemical screening of plants. J Pharm Sci 55 (3): 263

Gao Q, ZH Liu, Wu JL, Geng Y, Qian Z, Mei Tc, Gu XJ, Tanokura M Xue YL. Foliar application is an effective method or incorporating selenium into peanut leaf proteins with antioxidant activities. Food Res Intl 126: 108617. DOI: 10.1016/j.foodres.2019.108617.

Gogoi R, Loying R, Sarma N, Munda S, Pandey SK, Lal M. 2019. A comparative study on antioxidant, anti-inflammatory, genotoxicity, antimicrobial activities and chemical composition of fruit and leaf essential oils of LitseacubebaPers from North-east India. Industr Crops Prod 125: 131-139.

Harborne JB. 1987. Phytochemical Methods. Chapman and Hall, London.

Harun N, Syar'i W. 2002. The antioxidant activity of the extract of Dewa leaves in inhibiting the hepatotoxic properties of halothane with subanesthetic doses on mice J Pharmaceut Sci Technol 7 (2): 63-70.

Hashim Y Z H Y, Kerr PG, Abbas P, Salleh HM. 2016. Aquilaria spp. (agarwood) as source of health beneficial compounds: A review of traditional use, phytochemistry and pharmacology. J Ethnopharmacol 189: 331-360.

Herlina SA, Aziz, Kurniawati, Faridah DN. 2017. Changes of thymoquinone, thymol, and malondialdehyde content of black cumin (Nigella sativa L.) in response to Indonesia tropical altitude variation. Hayati J Biosci 24: 156-161.

Huda AWN, Munira MAS, Fitrya SD, Salmah M. 2009. Antioxidan activity of Aquilaria malaccensis (Thymelaeaceae) leaves. Pharmacogn Res 1: 270-273.
Khodadadi S, Nejadsattari T, Naqinezhad A, Ebrahimzadeh MA. 2015. Diversity in antioxidant properties and mineral contents of lliumparadoxum in the Hyrcanian forests, Northern Iran. Biodiversitas 16 (2): 281-287.

Khalil AS, Rahim AA, Taha KK, Abdallah KB. 2013. Characterization of ethanolic extracts of agarwood leaves. J Appl Industr Sci 1: 78-88.

Khristyana L, Anggarwulan E, Marsusi. 2005. Growth, saponin and nitrogen content of common plantain (Plantago major L.) tissue with gibberellic acid application (GA3). Biofarmasi 3 (1): 11-15.

Kuntorini EM, Dewi M, Misrina. 2016. Anatomical structure and antioxidant activity of red bulb plant (Eleutherine americana) on different plant age. Biodiversitas 17 (1): 229-233.

Kuo KL, Weng MS, Chiang CT, Tsai YJ, Lin-Shiau SY, Lin JK. 2005. Comparative studies on the hypolipidemic and growth-suppressive effects of oolong, black, pu-erh, and green tea leaves in rats. J Agric Food Chem 53: 480-489.

Mardawati E, Achyar CS, Marta H. 2008. Study of antioxidant activity of mangosteen rind extract (Garcinia mangostana L) in order to utilization of mangosteen rind waste in Pusphiang Sub-District of Tasikmalaya District. Final Report of Young Researcher (LITMUD). Padjajaran University, Bandung. [Indonesian]

Marliana S, Suryanti V, Suyono. 2005. The phytochemical screenings and thin layer chromatography analysis of chemical compounds in ethanol extract of labu siam fruit (Sechium edule Jacq. Swartz.). Biofarmasi 3 (1): 26-31. [Indonesian]

Mega IM, Swastini DA. 2010. Phytochemical screening and free antiradical activity of gaharu leaf methanol extract (Gyrinops versteegii). Chem J 4 (2): 187-192.

Molyneux P. 2004. The use of the stable free radical diphenylpicrylhydrazyl (DPPH) for estimating antioxidant activity Songklanakarin J Sci Technol 26: 212-219.

P.O.M. Ditjen 1995. Indonesian Materia Medica. Volume IV. Ministry of Health. Jakarta. P 321-337. [Indonesian]

Prakash A. 2001. Antioxidant activity. Anal Prog 19 (2): 1-4

Pranakhon R, Aromdee C, Pannangpetch P, 2015. Effects of iriflophenone 3-C- $\beta$ - glucoside on fasting blood glucose level and glucose uptake. Pharmacogn Mag 11: 82-89.

Sirait M. 2007. Phytochemical Guides in Pharmacy. ITB, Bandung. [Indonesian]

Soekmanto A, Apsari Y, Simanjuntak P. 2007. Antioxidant content of parts of mahkota dewa, Phaleria macrocarpa [Scheff] Boerl. (Thymelaceae). Biodiversitas 8 (2): 92-95.

Sumarna 2012.Cultivation of species agarwood producing. Forestry Research and Development Agency, Bogor. [Indonesian]

Surjanto, Batubara R, Ginting H, Silaban SF. 2015. Phytochemical screening of gaharu leaf extract and it potential test as antioxidant tea. Seminar Nasional MAPEKI XVII, Universitas Sumatera Utara, Medan, 11 November 2014.

Surjanto, Batubara R, Hanum TI, Pulungan W. 2019a. Phytochemical and antioxidant activity of gaharu leaf tea (Aquilaria malaccensis Lamk) as raw material of tea from middle Tapanuli District, North Sumatera Province.IOP Conf. Series: Earth and Environmental Science 260 (2019) 012101. DOI: 10.1088/1755-1315/260/1/012101.

Surjanto, Batubara R, Hanum TI, Julianti E. 2019b. Potency of fresh and rotten leaves of gaharu (WikstroemiatenuiramisMiq) Sumatera endemic as raw material of antioxidant-rich tea. IOP Conf Ser Earth Environ Sci 305: 012061. DOI: 10.1088/1755-1315/305/1/012061.

Trilaksani W. 2003. Antioxidants: type, source, mechanism of work and role to health. [Thesis]. Bogor Agricultural University, Bogor. [Indonesian]

Werdhasari A. 2014. Role of antioxidants for health. Biotech Journal Medisina Indonesia 3 (2): 59-68.

Yagura T, Ito M, Kiuchi F, Honda G, Shimada Y. 2003. Four new 2-(2phenylethyl) chromone derivatives from withered wood of Aquilaria sinensis. Chem Pharm Bull (Tokyo) 51 (5):560-564.

Yildirim I, Kutlu T. 2015. Anticancer agents: saponin and tannin. Intl J Biol Chem 9 (6): 332-340.

Zhou M, Wang H, Suolangjiba, Kou J, Yu B. 2008. Antinociceptive and anti-inflammatory activities of Aquilaria sinensis (Lour.) Gilg. Leaves extract. J Ethnopharmacol 117: 345-350. 